Elzbieta R. Perera MD FRCPC, Dmitar M. Vidic BSc RRT, Joel Zivot MD

\title{
Carinal resection with two high-frequency jet ventilation delivery systems
}

\begin{abstract}
A 76-yr-old man underwent carinal resection for squamous cell carcinoma through the right posterolateral thoracotomy approach. Ventilation was maintained by the use of two highfrequency jet ventilators, each attached to a separate catheter during the time of resection and reconstruction of the tracheal carina. These catheters were introduced through the endotracheal tube and positioned into the left and right main bronchi at the beginning of the tracheal resection. Then, conventional ventilation was replaced by high-frequency jet ventilation (HFJV) with different ventilatory variables for each lung. During two-lung jet ventilation there was good oxygenation, normocapnia and no cardiovascular complications. The principle advantage of using two separate high-frequency ventilators is that it allows for maximum ventilatory efficiency with lungs of different compliance.
\end{abstract}

Un homme de 76 subit une résection de la carène pour un épithélioma spino-cellulaire par thoracotomie postéro-latérale. Les échanges respiratoires sont assurés par deux appareil de jet ventilation à haute fréquence, chacun étant relié à une cathéter distinct pendant la durée de la résection et de reconstruction de la carène. Les cathéters sont introduits à travers une canule trachéale ordinaire et placés dans les bronches droite et gauche au début de la résection trachéale. Ensuite, la jet ventilation à haute fréquence adaptée à des paramètres différents pour chacun des poumons relaye la ventilation conventionnelle. Pendant la ventilation pulmonaire à deux ventilateurs, on obtient une bonne oxygénation, une normocapnie sans complications cardiovasculaires. Le principal avantage de l'utilisation de deux

\section{Key words}

ANAESTHESIA: thoracic;

EQUIPMENT: ventilators, high frequency;

LUNG: trachea, carina.

\footnotetext{
From the Department of Anaesthesiology, Mount Sinai Hospital, Toronto, Ontario.

Address correspondence to: Dr. Elzbieta Perera, Department of Anaesthesiology, Mount Sinai Hospital, 600 University

Avenue, Toronto, Ontario, M5G IX5.

Accepted for publication 29th August, 1992.
}

jet ventilateurs à haute fréquence réside dans le fait qu'on puisse ventiler efficacement deux poumons de compliances différentes.

\section{Case report}

A 76-yr-old man was admitted for investigation of progressive hoarseness and shortness of breath on moderate exertion. Laryngoscopy, bronchoscopy and mediastinoscopy revealed a squamous cell carcinoma of the right vocal cord as well as a squamous cell carcinoma of the carina adjacent to the origin of the left main bronchus. There was a history of cigarette smoking and exposure to coal and gold dust, as well as mild hypertension treated with enalapril $5 \mathrm{mg}$ od. He had undergone abdominal aortic aneurysm repair one year previously.

Physical examination was unremarkable. Blood pressure was $130 / 60 \mathrm{mmHg}$. Haemoglobin, electrolyte and creatinine concentrations, liver function tests, chest $x$-ray and ECG were all within normal limits. His preoperative arterial blood gas analysis breathing room air showed: pH 7.44; $\mathrm{PCO}_{2} 5.06 \mathrm{kPa}(38 \mathrm{mmHg}) ; \mathrm{PO}_{2} 10.8 \mathrm{kPa}$ $(81 \mathrm{mmHg}) ; \mathrm{HCO}_{3} 26 \mathrm{mmol} \cdot \mathrm{L}^{-1}, \mathrm{O}_{2}$ sat $96 \%$. Pulmonary function tests revealed a mild to moderate airflow limitation with hyperinflation and also moderate impairment of lung diffusion.

It was decided to resect the carinal tumour first, and subsequently to irradiate the laryngeal lesion. The patient was scheduled for excision and reconstruction of the carina through a right posterolateral thoracotomy.

\section{Conduct of anaesthesia}

The patient received premedication with glycopyrrolate $0.2 \mathrm{mg} \mathrm{im}$. Following placement of a lumbar epidural catheter for postoperative analgesia, general anaesthesia was induced with propofol $100 \mathrm{mg}$ and tracheal intubation was facilitated with succinylcholine $120 \mathrm{mg}$. A \#14 F Fogarty occlusion catheter, used as a bronchial blocker, was inserted into the right main bronchus followed by intubation of the trachea with a $9.0 \mathrm{~mm}$ endotracheal tube. The position of both was confirmed by fibreoptic bronchoscopy.

Initally, anaesthesia was maintained with oxygen $40 \%$, $\mathrm{N}_{2} \mathrm{O}$, halothane, fentanyl $100 \mu \mathrm{g}$ and muscle relaxation 
TABLE I High-frequency jet ventilators specifications

\begin{tabular}{lllll}
\hline Type of jet ventilator & Driving pressure & Respiratory rate & Inspiratory time & FrO \\
\hline $\begin{array}{l}\text { Instrument Development Corporation } \\
\text { Model VS } 600\end{array}$ & $\begin{array}{l}0-689 \mathrm{kpa}(0-100 \mathrm{psi}) \text { Limited to } 344 \\
\mathrm{kPa}(50 \mathrm{psi}) \text { due to wall inlet } \\
\text { pressure limit }\end{array}$ & $40-150 \cdot \mathrm{min}^{-1}$ & $20-70 \%$ & $\begin{array}{l}\text { Bird blender } \\
21-100 \%\end{array}$ \\
$\begin{array}{l}\text { Toronto Hospital General Division } \\
\text { manufactured by Biomedical }\end{array}$ & $0-344 \mathrm{kPa}(0-50 \mathrm{psi})$ & $90-240 \cdot \mathrm{min}^{-1}$ & $10-90 \%$ & Bird blender \\
\begin{tabular}{l} 
Engineering Department \\
\hline
\end{tabular} & & & $21-100 \%$ \\
\hline
\end{tabular}

TABLE II Changes in arterial blood gases during surgery and in recovery room

\begin{tabular}{|c|c|c|c|c|c|}
\hline Type of ventilation & $\mathrm{FlO}_{2}$ & $p H$ & $\mathrm{PCO}_{2} \mathrm{kPa}$ & $\mathrm{PO}_{2} \mathrm{kPa}$ & $\mathrm{O}_{2} \mathrm{Sal}$ \\
\hline Via endotracheal tube two lung anaesthesia & $40 \%$ & 7.4 & $\begin{array}{l}4.79 \\
(35.9 \mathrm{mmHg})\end{array}$ & $\begin{array}{l}33.72 \\
(253 \mathrm{mmHg})\end{array}$ & $99 \%$ \\
\hline $\begin{array}{l}\text { Via endotracheal tube with bronchial blocker } \\
\text { one lung anaesthesia }\end{array}$ & $100 \%$ & 7.39 & $\begin{array}{l}5.46 \\
(41 \mathrm{mmHg})\end{array}$ & $\begin{array}{l}61.18 \\
(459 \mathrm{mmHg})\end{array}$ & $99 \%$ \\
\hline HFJV one catheter $5 \mathrm{~min}$ from onset & $100 \%$ & 7.39 & $\begin{array}{l}5.20 \\
(39 \mathrm{mmHg})\end{array}$ & $\begin{array}{l}29.99 \\
(225 \mathrm{mmHg})\end{array}$ & $99 \%$ \\
\hline HFJV one catheter $10 \mathrm{~min}$ from onset & $100 \%$ & 7.37 & $\begin{array}{l}5.41 \\
(40.6 \mathrm{mmHg})\end{array}$ & $\begin{array}{l}7.82 \\
(58.7 \mathrm{mmHg})\end{array}$ & $89.2 \%$ \\
\hline HFJV two catheters $10 \mathrm{~min}$ from onset & $100 \%$ & 7.44 & $\begin{array}{l}4.37 \\
(32.8 \mathrm{mmHg})\end{array}$ & $\begin{array}{l}23.99 \\
(180 \mathrm{mmHg})\end{array}$ & $99.4 \%$ \\
\hline $\begin{array}{l}\text { Via endotracheal tube two lungs ventilation } \\
\text { after anastomosis }\end{array}$ & $40 \%$ & 7.35 & $\begin{array}{l}5.86 \\
(44 \mathrm{mmHg})\end{array}$ & $\begin{array}{l}38.39 \\
(288 \mathrm{mmHg})\end{array}$ & $99 \%$ \\
\hline $\begin{array}{l}\text { Spontaneous breathing with mask in } \\
\text { recovery room }\end{array}$ & $40 \%$ & 7.35 & $\begin{array}{l}5.86 \\
(44 \mathrm{mmHg})\end{array}$ & $\begin{array}{l}11.33 \\
(85 \mathrm{mmHg})\end{array}$ & $96 \%$ \\
\hline
\end{tabular}

with atracurium. The lungs were ventilated in the conventional manner with tidal volume $600 \mathrm{ml}$, rate eight breaths $\cdot \min ^{-1}$, and airway pressure $20 \mathrm{cmH}_{2} \mathrm{O}$. Monitoring included pulse oximetry, continuous end-tidal $\mathrm{CO}_{2}$ estimation, direct arterial pressure, urinary output and occasional arterial blood gases analysis.

During the surgical exposure of the carina, the bronchial blocker was inflated to allow collapse of the right lung. The inspired oxygen concentration was changed to $100 \%$ and $\mathrm{O}_{2}$ saturation was $99 \%$. At the incision of the trachea, a \#14 Fr suction catheter, with the aspiration port occluded and a single distal opening, was advanced through the endotracheal tube, which was withdrawn about $1 \mathrm{~cm}$. The surgeon introduced the tip of the catheter into the lumen of the left mainstem bronchus. Conventional ventilation was stopped and the catheter was attached to the jet ventilator I (Table I). The ventilator delivered $100 \% \mathrm{O}_{2}$ with respiratory rate $150 \mathrm{~min}^{-1}$, driving gas pressure $241 \mathrm{kPa}$ (35 psi) and inspiratory time of $50 \%$. Anaesthesia and muscle relaxation were maintained with infusions of propofol and atracurium respectively. During the first ten minutes of jet ventilation, blood gas analysis was satisfactory but the $\mathrm{O}_{2}$ saturation suddenly decreased to $88-89 \%$ (Table II). The bronchial blocker balloon was then deflated and a second catheter (\#12 Fr) was inserted through the endotracheal tube, introduced into the right main bronchus and connected to the second jet ventilator (Figure). The second ventilator settings were 140 breaths $\cdot \mathrm{min}^{-1}$, pressure $34 \mathrm{kPa}$ (5 psi) and inspiratory time of $50 \%$. This ventilation technique was continued for two hours and provided very good surgical exposure. The patient maintained satisfactory oxygenation, normocapnia and cardiovascular stability. After completing the anastomosis, the catheters and the bronchial blocker were removed. Conventional ventilation using oxygen $40 \%, \mathrm{~N}_{2} \mathrm{O}$ and halothane was restarted through the endotracheal tube with tidal volume $600 \mathrm{ml}$, respiratory rate $8 \mathrm{~min}^{-1}$, and airway pressure $20 \mathrm{cmH}_{2} \mathrm{O}$.

After reversal of the muscle relaxants, spontaneous respiration was resumed. Epidural morphine $5 \mathrm{mg}$ was given through the epidural catheter and ketorolac $30 \mathrm{mg}$ im was given for pain relief. The trachea was extubated at the end of the operation. In the recovery room the patient's vital signs were stable and he was pain free. 


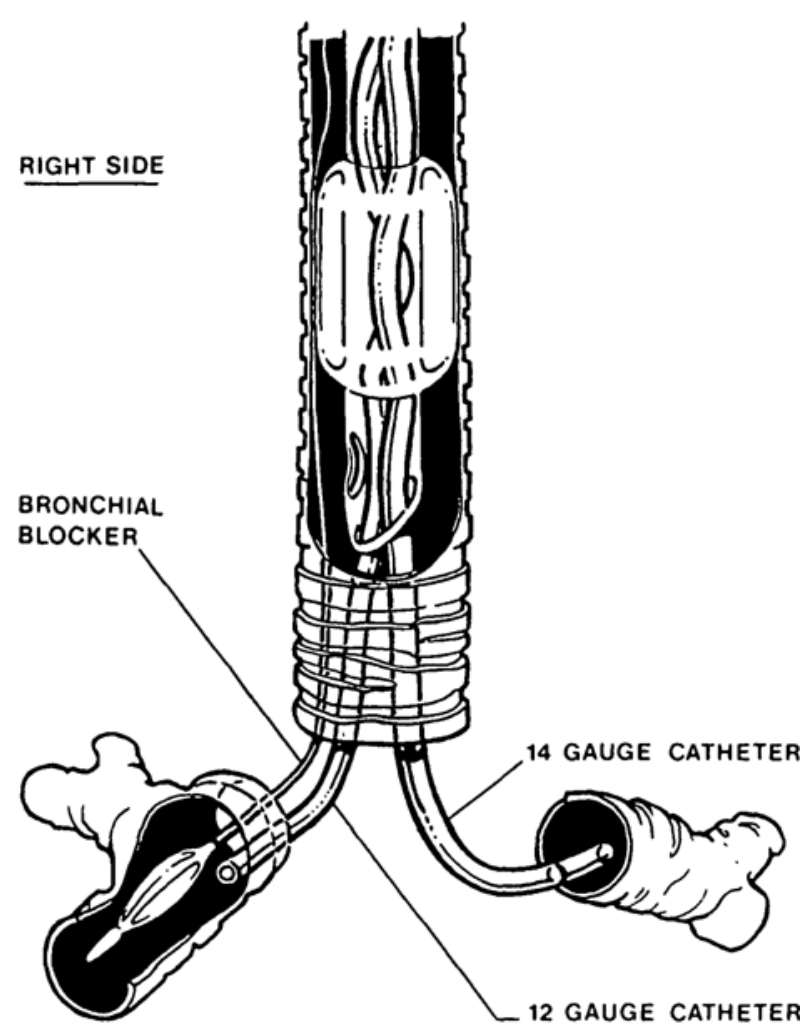

FIGURE Illustration showing position of catheters and blocker during high-frequency jet ventilation for carinal resection.

The subsequent hospital course was uneventful. Postoperative bronchoscopy revealed satisfactory healing and he was discharged home on the 11th postoperative day. Five months after surgery and subsequent irradiation of the larynx, he remains well and without evidence of recurrence.

\section{Discussion}

We present the management of ventilation during resection and reconstruction of tracheal carina, using two separate high-frequency jet ventilators, delivering oxygen to both lungs through separate catheters.

High-frequency jet ventilation (HFJV) has been recommended as a superior way of ventilating the patient with disrupted major airways, including those undergoing tracheal and bronchiál surgery. 1,46,9,18-23 This technique seems to satisfy the major requirements of pulmonary ventilation and anaesthesia for these procedures.

1 It provides an adequate gas exchange in the presence of surgically interrupted major airways. ${ }^{1,19}$ There is improved gas mixing and accelerated diffusion which result in good oxygenation and normocapnia. ${ }^{6}$ In addition, the presence of continuous positive airway pressure with auto-peep effect increases functional residual capacity (FRC) and decreases ventilation/perfusion (V/Q) mismatch. ${ }^{6,19}$

2 It ensures an unobstructed surgical field with free access to the circumference of the trachea and bronchi for airtight anastomosis and repair. ${ }^{1,5,6,19}$ The presence of the endotracheal tube is not essential, and a small catheter in the airways permits unhurried and accurate reconstruction without the need for temporary interruption of ventilation. $1,69,20$

3 It reduces the motion of airways and mediastinum. 1,6

4 It decreases the danger of aspiration of blood into the airways distal to the resection due to the continuous outflow of gases with use of HFJV. ${ }^{6}$

However, the use of HFJV requires that anaesthesia is provided by the intravenous route with an adequate degree of muscle relaxation.

Several anaesthetic techniques to allow for resection and reconstruction of trachea and carina have been reported. ${ }^{1,3-5,7-15}$ The use of cardiopulmonary bypass carries the danger of bleeding secondary to systemic anticoagulation. $1,3,5,8$ Many carinal reconstructions have been successfully performed with the use of a single long endotracheal tube advanced into the left main bronchus for the time of resection. ${ }^{25,8}$ or with a secondary tube or tubes inserted from the operating field into dissected bronchial stumps and removed when the anastomosis was completed. ${ }^{1,2,4,5,7,14}$ Double lumen tubes have a potential disadvantage of trauma at the site of the lesion. The main problem with the use of a tube is its restriction of surgical access and the need for temporary removal of the tube to facilitate anastomosis of the posterial wall of airways. Intermittent extubations result in variable periods of apnoea and the possibility of bronchial stumps being plugged with blood and debris.

Tracheal and carinal resections have been performed successfully with low-frequency jet ventilation, utilizing the Venturi principle. ${ }^{3,5,12,13,15}$ This technique provides good surgical access, but carries a danger of $\mathrm{CO}_{2}$ retention either from hypoventilation or from the reentrainment of expired $\mathrm{CO}_{2}$ from the thoracic cavity. $5,9,13$ Satisfactory gas exchange was reported in 18 patients undergoing tracheo-bronchial reconstruction with the use of high-flow ventilation technique. ${ }^{9}$ However, we found that with this technique there is an excessive mobility of the tip of the catheter making it difficult to keep inside the bronchial lumen. There is also a considerable spraying of blood across the operating field caused by the highflow oxygen.

High frequency ventilation (HFV) was applied for the first time in transthoracic resection of tracheal stenosis by Eriksson in 1975. The authors suggested using two insufflation catheters for lesions in close proximity to the carina. ${ }^{4}$ 
In 1982 El-Baz et al. presented a new technique of one-lung high-frequency positive-pressure ventilation (HFPPV) in six patients. HFPPV was applied through a single plastic catheter inserted into left main bronchus. ${ }^{6}$ In 1987 Watanabe et al. reported 21 patients undergoing major airway reconstructive surgery with use of HFJV. HFJV has been applied in two cases to both lungs simultaneously using two catheters and two high-frequency oscillation ventilators. ${ }^{20}$ Crinquette $e t$ al. describe separate two lung HFJV through two catheters and two ventilators used for carinal resection in the patient with COPD, and recommend this technique for patients with low pulmonary reserve. ${ }^{22}$

Our choice of technique was based on our previous experience with HFJV and reports from literature describing the management of ventilation during carinal resection.

Initially we planned to use HFJV for the left lung only, but arranged for the second HFJ ventilator to be available should gas exchange with one-sided HFJV prove to be inadequate. The insertion of the right bronchial blocker with subsequent right lung collapse in the first part of the operation not only facilitated surgical exposure of the carina, but also served as a test of the adequacy of oxygenation during one-lung conventional IPPB. The ventilatory variables of HFJV for the left lung were adjusted according to our previous experience with the technique and recommendations of others. $5,6,8,20,21$ We were unable to determine the definite cause of decrease in oxygen saturation, which occurred approximately ten mintues after the onset of HFJV to the left lung, but we suspected it was either compression of the left lung or bleeding. In this situation there were several options for the rapid relief of hypoxia:

1 Increase the driving gas pressure (DGP). This carries the risk of barotrauma and worsening of $V / Q$ abnormalities. There is also some time delay when making gradual presure adjustments and we felt that we could not afford this delay, particularly as the results were uncertain.

2 Ventilate the right lung through a second catheter connected to the same HFJ ventilator with Y piece. ${ }^{23}$ However, the single jet ventilator does not permit establishment of separate ventilating variables for each lung. Considering the differences in lung compliance which occur in the lateral decubitus position, HFJV delivered equally to each lung may result in hypoventilation of the dependent lung and hyperinflation of the nondependent one. ${ }^{22}$

3 Use another jet ventilator with a separate ventilating catheter for the second lung. This was our technique of choice.

We had to use a smaller size catheter for the right lung than for the left, because we could not accommodate two $14 \mathrm{G}$ catheters inside the endotracheal tube. In general, the size of catheters is determined by the internal diameter of the endotracheal tube. We feel that the catheters should have some stiffness to ease manipulation and provide stabilization inside the bronchial stumps.

To minimize as much as possible the expansion and mobility of the right lung, we chose the lowest DGP for the second HFJV, which could correct hypoxia. Satisfactory oxygenation was achieved with DGP as low as 5 psi, leaving the right lung almost collapsed with no mobility perceived by the surgeon and minimal blood splattering. During the two hour period of HFJV with two catheters and two ventilators there was satisfactory ventilation and oxygenation, without evidence of cardiovascular compromise. The surgical exposure and access to anastomotic sites was excellent through the whole procedure.

Like any other technique, HFJV is not without disadvantages. The most important is the potential for gas trapping and barotrauma. ${ }^{16-18,21,23}$ Ventilation of uninterrupted airways requires careful airway pressure monitoring; however, in carinal resection the open bronchus or trachea proximal to the catheter tip provides an exit for the outflow of gases to the atmosphere. ${ }^{6}$ This ensures an adequate safety margin if the appearance of the lung and the position of the tip of catheter; are continuously observed. ${ }^{23}$ Other disadvantages are the drying and cooling effects of gases. ${ }^{17}$

In conclusion, this report suggests that the use of HFJV with two catheters and two ventilators provides good gas exchange and operative conditions for carinal resection.

\section{Acknowledgements}

Authors would like to thank Dr. Melvyn Goldberg, thoracic surgeon, for presenting us with this interesting case; Department of Respiratory Therapy of Mount Sinai Hospital for making available the necessary equipment; Dr. J. Fisher for reviewing this paper; and also Mrs. Josephine Sham for her help in preparing this manuscript.

\section{References}

1 Benumof JL. Anaesthesia for Thoracic Surgery. Ist ed. Philadelphia: W.B. Saunders Co., 1987; 291-2, 349-55.

2 Tsuchiya R, Goya T, Naruke T, Suemasu K. Resection of tracheal carina for lung cancer. J Thorac Cardiovasc Surg 1990; 99: 779-87.

3 Baraka $A$. Oxygen-jet ventilation during tracheal reconstruction in patients with tracheal stenosis. Anesth Analg Curr Res 1977; 56: 3: 429-32.

4 Erikssọn I, Nilsson L-G, Nordström S. Sjöstrand U. Highfrequency positive-pressure ventilation (HFPPV) during 
transthoracic resection of tracheal stenosis and during perioperative bronchoscopic examination. Acta Anaesthesiol Scand 1975; 19: 113-9.

5 Young-Beyer P, Wilson RS. Anesthetic management for tracheal resection and reconstruction. J Cardiothorac Vasc Anesth 1988; 2: 6: 821-35.

6 El-Baz N, Jensik R, Faber LP, Faro RS. One-lung highfrequency ventilation for tracheoplasty and bronchoplasty: a new technique. Ann Thorac Surg 1982; 34: 564-70.

7 Theman TE, Kerr JH, Nelems JM, Pearson FG. Carinal resection. A report of two cases and a description of the anesthetic technique. J Thorac Cardiovasc Surg 1976; 71: 2: 314-20.

8 Grillo HC. Carinal reconstruction. Ann Thorac Surg 1982; 34: $356-72$.

9 McClish A, Deslauriers J, Beaulieu M, et al. High-flow catheter ventilation during major tracheobronchial reconstruction. J Thorac Cardiovasc Surg 1985; 89: 508-12.

10 Abou-Madi MN, Cuadrado L, Domb B, Barnes J, Trop $D$. Anaesthesia for tracheal resection: a new way to manage the airway. Can Anaesth Soc J 1979; 26: 1: 26-8.

11 Ismail $A B$. Anaesthesia for tracheal resection. Modified use of the carden tube. Can Anaesth Soc J 1979; 26: 2: 134-7.

12 Lee P. English ICW. Management of anaesthesia during tracheal resection. Anaesthesia 1974; 29 : 305-6.

13 Clarkson WB, Davies JR. Anaesthesia for carinal resection. Anaesthesia 1978; 33: 815-9.

14 Geffin B. Bland J. Grillo $H$. Anesthetic management of tracheal resection and reconstruction. Anesth Analg Curr Res 1969; 48: 884-90.

15 Macnaughton FI. Catheter inflation ventilation in tracheal stenosis. Br J Anaesth 1975: 47: 1225-7.

16 Froese $A B$. High frequency ventilation: current status. Can Anaesth Soc J 1984; 31: S9-S12.

17 Smith $B E$. High frequency ventilation: past, present and future. Br J Anaesth 1990; 65: 130-8.

18 Standiford TJ, Morganroth $M L$. High frequency ventilation. Chest 1989; 96: 1380-9.

19 El-Baz N, Holinger L, El-Ganzouri A. et al. Highfrequency positive-pressure ventilation for tracheal reconstruction supported by tracheal T-tube. Anesth Analg 1982; 61: 796-800.

20 Watanabe Y, Murakami S, Takashi I, Murakami T. The clinical value of high-frequency jet ventilation in major airway reconstructive surgery. Scand J Thorac Cardiovasc Surg 1988; 22: 227-33.

21 Giunta F, Chiaranda M, Manani G, Giron GP. Clinical uses of high frequency jet ventilation in anaesthesia. $\mathrm{Br} \mathrm{J}$ Anaesth 1989; 63: 102S-106S.

22 Crinquette $V$, Wurtz A, Leroy $S$, Dalmas $S$. Résection et reconstruction de la bifurcation trachéale sous jet ventilation a haute fréquence séparée sur les deux poumons. Ann Chir 1989; 43: 673-6.
23 McKinney M, Coppel DL, Gibbons JR, Cosgrove J. A new technique for sleeve resection and major bronchial resection using twin catheters and high frequency ventilation. Anaesthesia 1988; 43: 25-6. 